\title{
Corporate power in the agro-food system and the consumer food environment in South Africa
}

\author{
Stephen Greenberg
}

\begin{abstract}
This contribution maps the South African agro-food system with a focus on corporate ownership and power, inspired by value chain work applied to the food system as a whole. Corporations tend to dominate some nodes, for example input supply, grain storage and handling, and feedlots. Other nodes have a corporate core but with a wide number of smaller economic actors, for example agricultural production, food manufacturing, wholesale and retail, and consumer food service. This wide number of actors points to possible areas of intervention to boost livelihoods by supporting their economic activities. The paper considers the influence of corporations in structuring consumer perceptions on food quality and health, from input into apparently neutral dietary-based guidelines to advertising. Financialisation in the food system, including the institutionalisation of share ownership and the rise of agri-investment companies, and the multi-nationalisation of South African agro-food capital especially into Africa, have implications for the ability of the nation state to regulate activities in the agro-food system. The paper concludes with some recommendations for further work.
\end{abstract}

\section{Introduction}

This contribution investigates the structure of the South African agro-food system, with a particular focus on the role of corporations. It was commissioned for the Centre of Excellence in Food Security to consolidate knowledge about specific topics and to develop a research agenda for further work. The report provides an overview of some of the key features of the South African food system, and provides a conceptual platform for further research.

There is ample evidence that we are in the era of a corporate-led food regime. That is, corporate interests are dominant, both materially and in the ways in which the food system is understood and discussed. No overall mapping of the South African agro-food system or of corporate power in the system has been conducted to date. While there is some sense of corporate power in retail and manufacturing in particular, there is no systematic review throughout the system. Bits and pieces of information are scattered about and these have been brought together, inspired by value chain work applied to the system as a whole, expanded on and updated, and initial efforts have been made to identify and fill gaps. 
The mapping starts with a schematic presentation of the overall agro-food system structure and the role of corporations in it. A short overview is followed with more detail on major nodes, including inputs to primary agriculture, logistics, primary agricultural production, food manufacturing, wholesale and retail, and food service (prepared food consumed outside the home). The mapping is mostly descriptive, with the purpose of establishing a clear picture of the whole system and the many parts to it. This will allow prioritisation for more in-depth research.

There is a brief overview of the strong corporate influence in shaping the consumer food environment (CFE). The CFE essentially deals with the factors affecting the environment in which consumers make their food choices. Powerful corporate players actively shape the availability, affordability and acceptability of foods, and with this the broader CFE. These dynamics are implicated in the nutritional transition to unhealthy diets and subsequently a number of public health concerns. The corporate-dominated agro-food system is, therefore, a key mediator of food security for South Africans.

The paper then goes on to describe and discuss some trends and dynamics of the contemporary food system, including financialisation and institutionalisation of ownership, and the multinationalisation of South African agro-food capital (referring to capital in its productive form). The paper concludes with some reflections and a further research agenda. These indicate a number of under-researched parts of the system that could benefit from further work, including a livelihood focus in nodes with a large number of economic actors outside of or only indirectly related to the corporate core, especially agricultural production, retail and consumer food service.

\section{The changing South African agro-food system}

Corporate power in the food system has increased markedly since the breakdown of the Bretton Woods system and, in South Africa, the transition from apartheid. It was after this time that neoliberal hegemony, strongly favouring corporate self-regulation, really took hold (see Mirowski 2014). Global value chains have come into their own, and there has been a general, if uneven, shift in control of productive processes from manufacturing to retail (Burch and Lawrence 2009, 268). The contemporary agro-food regime is characterised by the international extension and externalisation of manufacturing chains previously internalised within the organisational boundaries of vertically integrated corporations and, to a large extent, within nation states (Raikes, Jensen, and Ponte 2000, 3-4). World market prices have become decoupled or separated from actual regional production costs, with global political mechanisms at the signing of the General Agreement on Tariffs and Trade (GATT) and then the World Trade Organization (WTO) shaping prices (McMichael 2005; Moore 2010, 240). This simultaneously indicates an ongoing role for the state and creates opportunities for concentration of production and centralisation of capital in the agro-food sector. Nation states remained at the centre of institutional and regulatory processes, but favouring corporate interests. 
The 'third technological revolution' has seen gains in labour productivity, especially from the introduction of new information and communications technologies (ICTs) rooted in computerisation and information digitisation, and the rise to prominence of network forms of organisation (Castells 1996). ICTs have enabled just-in-time inventory management, flexible and agile supply chains and other production advances, with greater capacity to analyse large data sets (Busch 2010, 343), looking for and interpreting patterns. The enhanced ability to mine and use information facilitates the rise of intellectual property protection as a defining feature of value capture and extraction in the corporate regime.

These technologies have revolutionised coordination activities, modifying both inter-firm relations (competition and cooperation) and producer-consumer interfaces. Goods with high informational content may be costly to create, but they can circulate at a near-zero marginal cost. The result is increasing returns to scale (decreasing average cost). The first consequence of growing returns to scale is a tendency towards concentration: the greater the production, the lower the average cost, giving a competitive advantage to the largest structures. The combination of scale and network effects results in the elaboration of business models which emphasise the necessity of being among the first to enter the market (Aglietta and Reberioux 2005, 14-15).

For South Africa, the end of the Bretton Woods system globally generated a domestic monetary crisis, and crisis response congealed into what came to be neo-liberal policies, both nationally and globally. In every country these processes differ, based on unique histories, levels of capitalist development and integration, and existing institutions and relations of power. But common themes across the board are processes of privatisation, trade liberalisation, state deregulation and corporate self-regulation. These also occurred in South Africa as the agro-food system made the transition from a system built on the basis of tight nation-state control to one where global markets and corporations gained influence (Bernstein 2013; Greenberg 2010).

Three notable developments in the South African context were: the signing of the Uruguay Round of GATT which led to the formation of the WTO in 1994 and locked countries into trade agreements with major implications for systems of production and distribution; the dismantling of the statutory regulatory systems governing agricultural and food products and their replacement with a combination of greater market forces and industry self-regulation, culminating in the Marketing of Agricultural Products Act (MAPA) of 1996; and amendments to the Cooperatives Act in 1993 which allowed the cooperative infrastructure to be removed from farmer control, and then corporatised and privatised (Amin and Bernstein 1996; Bayley 2000). Combined, these opened the door to expansion of corporate power in the South African system.

\section{Mapping corporate power in the contemporary South African agro-food system}

This section is inspired by value chain work applied to the food system as a whole to offer an initial mapping of corporate involvement in the agro-food system. The value chain approach usefully breaks down the life cycle of a commodity into different phases or 
nodes in the production and value addition process, and analyses the relations in each of these nodes. The overview of the food system here is structured on the basis of specific nodes of activity through which agro-food commodities pass and value is added, with a focus on companies that operate across multiple commodity chains. Figure 1 provides a rough diagrammatic overview of the South African agro-food system, highlighting key corporate actors. Figure 2 provides a preliminary quantification of the value of different nodes or parts of the agro-food system. The largest node of activity is wholesale and retail, followed by food manufacturing and then primary agricultural production. This is total value rather than value addition, so it is not surprising that downstream nodes are larger than upstream ones. However, it does indicate the relative value under control in each node.

Some nodes tend to be dominated by corporations, for example input supply, grain storage and handling, and feedlots for commercial livestock. Other nodes have a strong corporate core but there is a far wider periphery, for example primary agricultural production, food manufacturing, and food wholesale and retail. The latter three are also the largest nodes in the system by value. It is important to note that nodes have their own centres of power and control, and also that the distribution of power and control in the system varies by commodity. There is no simple story of buyer (specifically retail) domination throughout the agro-food system. Seed, fertiliser and machinery, for example, seem to be producerdriven in the sense that production innovations rather than consumer demands drive change, although it will obviously be dialectical. The relationships between food manufacturers and retailers are also likely to be more complex than simply being buyer driven.

Innovation is critical to manufacturing competitiveness, and this means manufacturers may seek to shape demand through the creation of 'new' products rather than merely responding to demand channelled through retailers. 


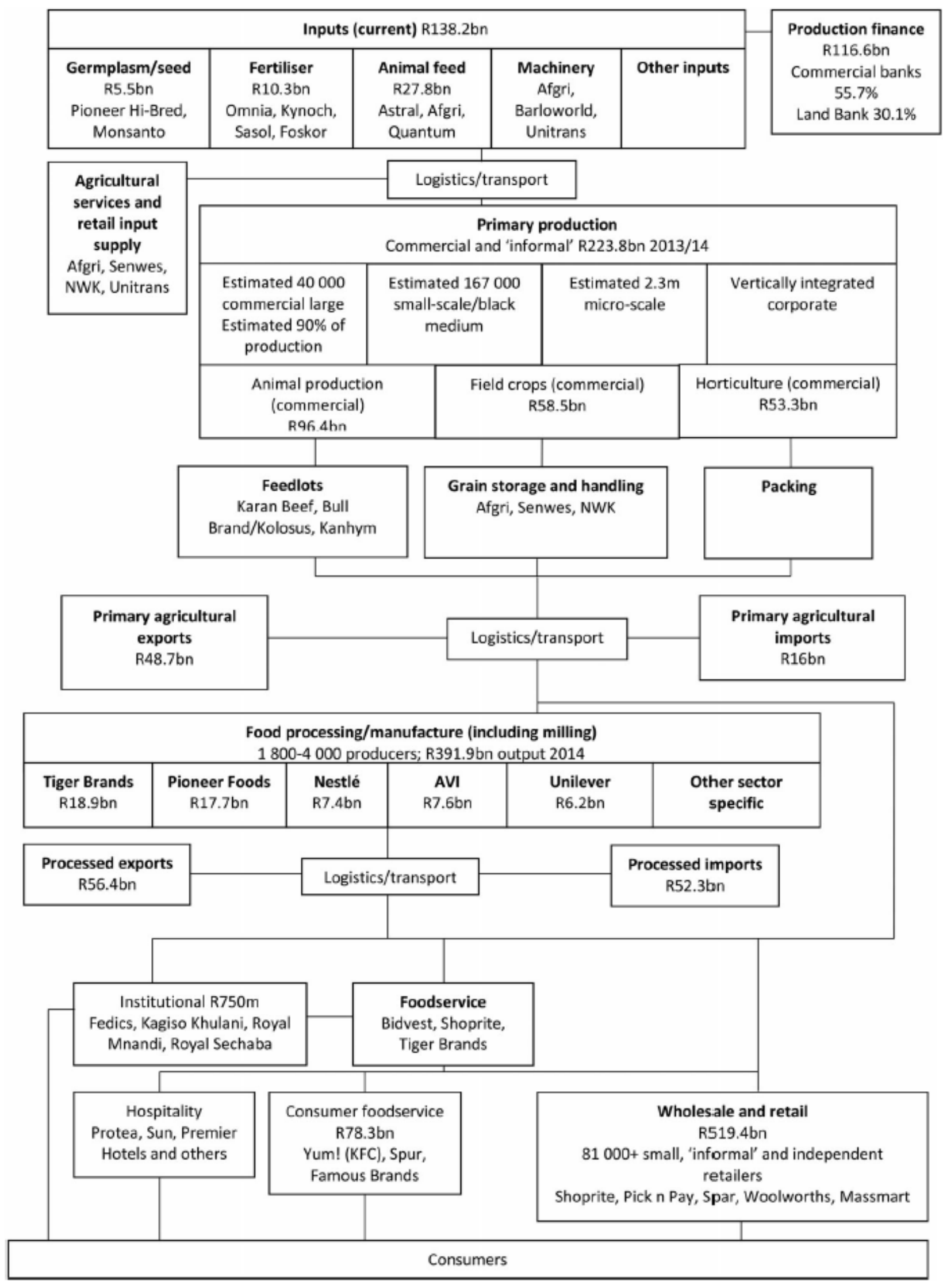

Figure 1. Schematic overview of South African agro-food system structure. 


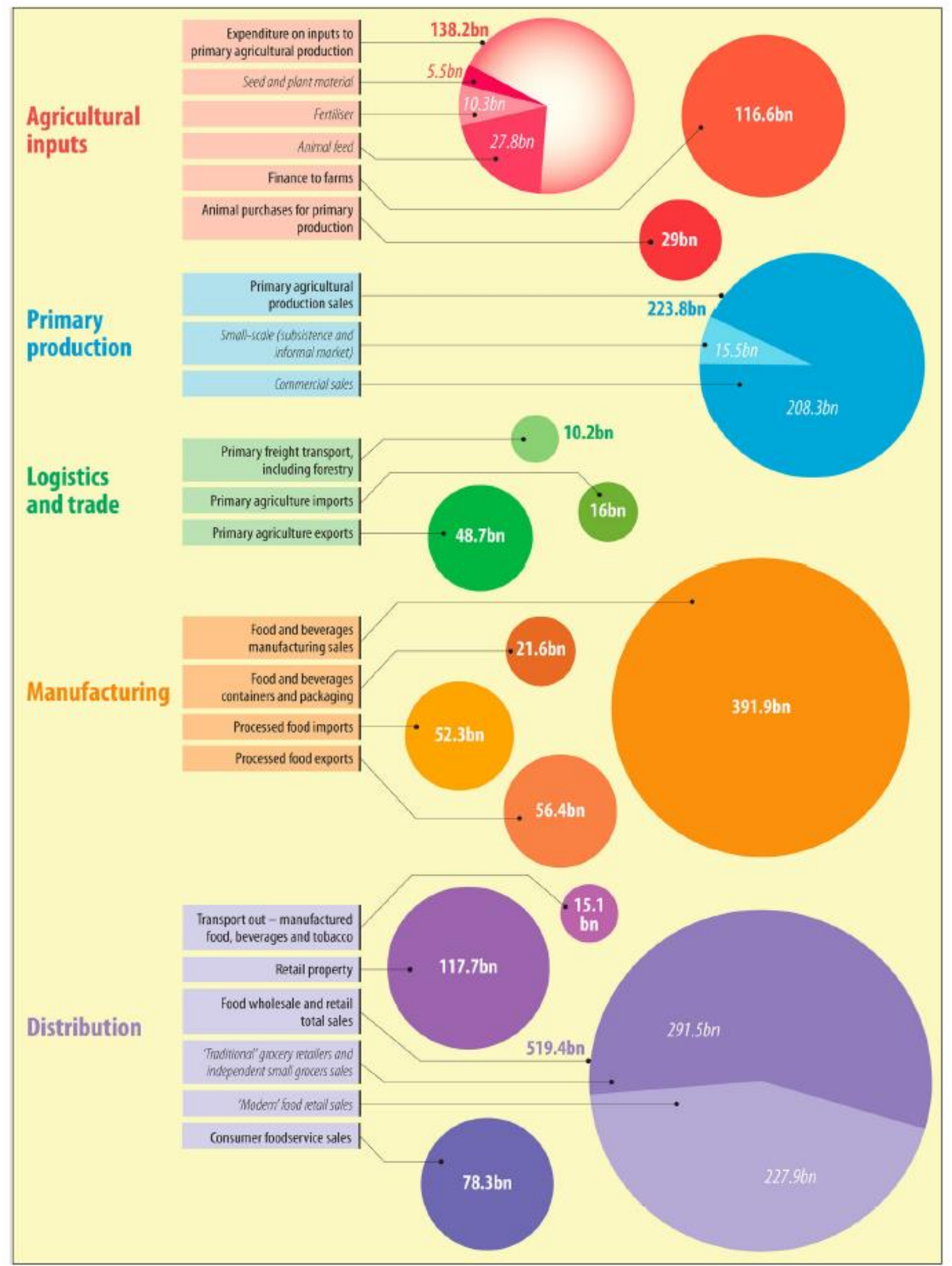

Figure 2. Preliminary quantification of value in selected nodes and activities in the agro-food system, 2014.

Note: Thanks to Dudu Coelho for assistance with the infographic. 


\section{Inputs to primary production}

Agricultural inputs are not well mapped in the South African agro-food system. There is some data from Statistics South Africa (Stats SA) on expenditure, and the Department of Agriculture, Forestry and Fisheries (DAFF) has annual updates on price indices, but not amounts spent. There is some work on corporate power in seed, fertiliser and agrochemicals (ACB 2009). Research and development, education and training, and technical and management expertise are hidden from outsiders. Further research on these dimensions is required.

Total current expenditure on farms in 2013 was R 178.5 billion, divided into: inputs, R 130.1 billion (73 percent); animals, R 27.6 billion (15 percent); and salaries and wages, R 20.7 billion (12 percent). Major input costs were: animal feed, $\mathrm{R} 26.6$ billion (20 percent of total); repairs, maintenance and licences, R 10.2 billion ( 8 percent); fertilisers, $\mathrm{R} 10$ billion ( 8 percent); and fuel, R 8.3 billion (6 percent) (Stats SA 2013, 7). Some of the more significant other inputs include depreciation, packing materials, contractors, seed and planting materials, and animal and crop remedies.

The different inputs have their own dominant corporations. The commercial animal feed sector tends to be vertically integrated, especially within the large poultry producers. Major members of the Animal Feed Manufacturers' Association (AFMA) are Meadow Feeds (Astral Foods), Epol and Foodcorp (both RCL Foods), Nutri Feeds (Country Bird), Afgri Animal Feeds, Nova Feeds (Quantum), VKB Agriculture, and De Heus (subsidiary of Dutch multinational). For the poultry companies in particular, feed is a major source of profit and in recent years has even offset losses in poultry production. The vertically integrated companies produce feed for their internal operations as well as for sale to others. Animal feed tends to employ far fewer workers than poultry operations. Animal feed accounts for a small share of overall revenue produced by the vertically integrated poultry producers, but animal feed operations account for most of the operating profit. Amongst grain traders, Cargill and Louis Dreyfus handle 70 percent of maize trading in South Africa (ACB 2013, 17).

Agricultural machinery is mostly imported with domestic and multinational corporations (MNCs) operating as agents and after-sales support, sometimes with exclusive brand rights in South Africa and regionally. Imported agricultural machinery ${ }^{1}$ was valued at R 6.5 billion in 2014 (DTI 2015). Companies in the market include Afgri, Barlo-world Agriculture, Bell Equipment, Deere \& Co, Agco, Dipla and Landmech. Afgri is the single largest John Deere franchise in Africa, with 11 centres in South Africa, two in Zimbabwe, one in Zambia, one in Ghana and a John Deere franchise in Australia. It had a 30 percent South African market share for tractors in 2013 (Afgri 2013). Other companies provide on-farm services which may include leasing of machinery. No publicly available work has been done on this sector yet.

${ }^{1}$ This includes specifically agricultural machinery, but not agriculture's share of general-purpose machinery, e.g. transport, forklifts, graders, etc. 
As with machinery, a high proportion of fertiliser raw materials and finished product are imported. In the mid-2000s all potash and 40-60 percent of nitrogen was imported, while domestic production accounted for around 90 percent of phosphate (ACB 2009, 49). Fertiliser production requires procurement of the raw material inputs with some links to the mining sector, and then blending of bulk and specialist fertilisers. The fertiliser industry was built under state protection prior to the 1980s, with state-owned enterprises Foskor and Sasol dominant. After deregulation, the industry was unable to sustain itself; factories were closed and South Africa became a net importer of fertiliser from around 2000 (ACB 2009). Fertiliser imports in 2000 were valued at $R 858$ million, rising rapidly to $R 7.4$ billion in 2014 (DTI 2015). Penalties for collusion in 2009 (Competition Tribunal 2009) led to a restructuring of the industry, but little work has been done since then to track changes and consolidation in the industry. The main companies are Sasol, Foskor and Omnia, all operating as multinationals. For Sasol, a very large petro-chemical corporation, fertiliser production is a small side business. Kynoch was the fertiliser market leader with an estimated market share of 40 percent in 1999 (M2 1999), but with an unknown share now. Yara owned Kynoch between 2005 and 2009, and the brand was taken off the market. Yara withdrew from the South African market after the Competition Tribunal ruling, and Kynoch is now under the ownership of East African multinational Export Trading Group.

Seed is included in Figures 1 and 2 mainly because it is an important input where corporate power is very concentrated, especially in maize, wheat and vegetables. Maize seed constituted 57 percent of the total seed market in 2014 (see Appendix 1). US multinationals Pioneer Hi Bred/Pannar and Monsanto are the biggest corporations in the seed sector. The largest remaining domestic company is Zaad, incorporating Agricol and Klein Karoo Seed, owned by Zeder (see Figure 3). The public (but corporatised) Agricultural Research Council holds significant plant breeders' rights (ACB 2009). Pioneer Hi-Bred/Pannar, Klein Karoo and Monsanto owned 62 percent of registered maize seed varieties in 2013 (ACB 2013, 17).

Retail input supply and wider agri-services are another poorly documented realm. Agriservices is a very broad term, ranging from insurance to retail input sales to on-farm contracting services, including labour brokering. Afgri, Senwes and NWK tend to be dominant in input delivery and agri-services, and have a number of partnerships and joint ventures between them. A trend is the move towards on-farm contract services, with logistics and agri-services corporations such as Unitrans and Afgri involved in such activities. For example, Unitrans' agricultural sub-division is involved in contracted load and haul services, harvesting, land preparation, bush clearing, infrastructure development and estate ancillary services (KAP Industrial 2014, 37).

\section{Logistics}

Logistics is a key factor throughout the system. Logistics functions include supply chain and network design, freight forwarding and clearing, transport, warehouse design and optimisation, warehousing and storage, inventory management, integration services, distribution and fulfilment, and demand management. Supply is structured around nodes 
with production networks that may consist of thousands of suppliers radiating from them (Sturgeon 2000). The primary objective is the supply of the right input at the right time in the right quantity for continuous production, with secondary objectives of resource use efficiency, integration of business processes along the supply chain, and cost and efficiency of supply and flow of materials from source to destination.

These are related to corporate concentration and the emphasis on meeting return on investment targets (Aglietta and Reberioux 2005). Shareholders exert pressure to reduce costs each and every year, and this flows through the supply chain. A recent trend is towards integrated supply systems. End-to-end integration of supply chain functions is considered the next major shift required to retain competitiveness (CSIR 2013, ii). Integrated systems drive down excess buffer stock and associated costs. Advances in ICT have facilitated and enabled real-time sharing of information, flexible specialisation in production, materials and resource planning and flows, and 'customer relationship management' and data mining to predict and shape customer demand (Kaplinsky and Morris 2001, 94-95). South Africa tends to lag behind these developments; in particular, South African companies still operate in silos with supply chains designed for individual companies, rather than throughout the chain (CSIR 2013).

Two main areas of logistics are farm to factory (primary freight) and factory to wholesale/retail (secondary freight). These may include cold chains, which benefit from an integrated modular approach so the chain is unbroken. Primary freight (including forestry) was valued at R 10.2 billion in 2014, while secondary freight (including beverages and tobacco) was valued at R 15.1 billion (Stats SA 2014a, 2014b, 2015b). Further work will need to be commodity specific. Companies with significant agro-food logistics operations across commodities include both outsourced operators, like Bidvest or Imperial, and in-house operations, like most of the retailers and manufacturers have. It should be noted that agrofood logistics is diverse, with large corporations operating alongside smaller companies and less formal operators such as 'bakkie traders', who purchase produce at the farm gate for distribution especially in small towns and rural areas (Cousins 2013; Manyelo, Van Averbeke, and Hebinck 2014). 


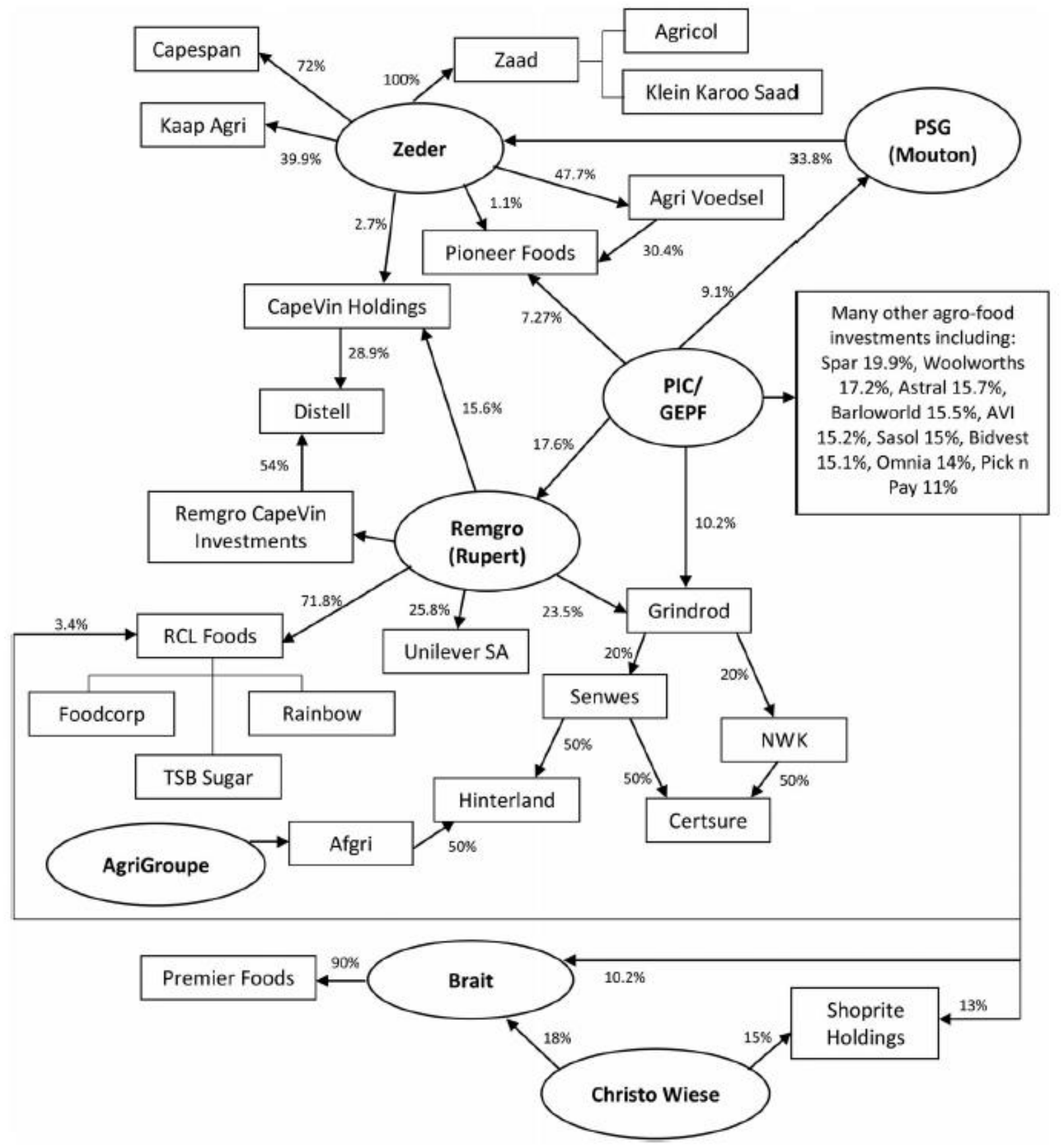

Figure 3. The agri-investment web, 2014.

In South Africa, at a large-scale commercial level, rail historically dominated freight and logistics through the state-owned South African Transport Services (later Transnet). After deregulation there was a rapid shift to road transport for flexibility and cost reasons (CSIR 2013). Transnet still plays a role, but bulk mining is dominant and agro-food products are a relatively small component of its total freight. Only around 5 percent of non-mining freight was moved by rail in 2012 (CSIR 2013, 40). There is a good national road network but decaying provincial infrastructure, including damage from trucks carrying 'rail-friendly' cargo (CSIR 2013, iii). Efforts are being made to shift freight back to rail. This is more ecologically friendly, but remains inflexible (e.g. containers must be full before they can 
move) and costly. There are some joint ventures or public-private partnerships (PPPs) between Transnet and private logistics companies, including Barloworld, Imperial and Unitrans (CSIR 2013, 66), on integrated inter-modality (CSIR 2013, 45).

The biggest logistics and transport corporations operating in South Africa are diversified across a number of economic fields, e.g. mining, industrial manufacture, and food products. Agriculture and fast-moving consumer goods are a smaller component of the businesses, and the share is difficult to extract from the available information. The largest companies operating in the sector appear to be Bidvest, Imperial and Barloworld, with Unitrans (subsidiary of KAP Industrial) also active on a smaller scale. Bidvest is by far the largest by market capitalisation, but a significant portion of its operations are outside South Africa. More investigation is required to map activities in the agro-food system specifically.

Trends in logistics include a growth in outsourcing of logistics (especially transport, storage, distribution and operations planning); consolidation in the retail supply chain and rationalisation of logistics services provider capacity; and increased engagement by business on their inbound supply chains (transport efficiencies, reduced inventories, integrated planning) (Imperial Holdings 2014, 56). Outsourcing of logistics, including planning, is fairly common, which is quite surprising given the centrality of control over the supply chain. Companies outsourcing logistics may opt to go with one large operator or may prefer to reduce dependency on a single service provider and distribute the activities amongst a number of smaller suppliers, where the lead firm will have greater control over the process and more flexibility.

On the other hand, a number of agro-food corporations, especially in manufacturing and distribution, have in-house logistics divisions that perform these functions within the corporation but may also sell logistics and transport services to other companies. An example is RCL Foods with Vector Logistics, which provides in-house services to subsidiaries Foodcorp, Rainbow and TSB, and also provides primary warehousing and transport, principal secondary distribution (to retailers, wholesalers and general trade) and customer secondary distribution (a full basket of products directly to customer outlets) to many clients, ranging from I\&J in fisheries to Pick n Pay in retail, and most of the large consumer food service outlets (RCL Foods 2014, 12-13). Pioneer Foods and AVI also have centralised procurement and logistics. Retailers have their own distribution fleets.

Wholesalers and retailers are at the forefront of supply chain management innovations, copying Walmart's globally successful operations. Walmart's supply chain innovations are based on centralised distribution; tight supply chain management built around new ICTs and computing power; data mining and analysis to forecast demand; and global sourcing and the elimination or redistribution of supply chain functions to transfer less profitable activities to suppliers and to absorb more profitable activities, including direct sourcing where it is profitable/cost saving to do so (Wulfraat 2011; Mack 2012). Consumers are recruited as allies to force down prices in the supply chain. Local retailers have adopted these and other global innovations in supply chain management over the past decade. 


\section{Primary agricultural production}

Commercial agricultural production was valued at R 208.3 billion in 2013/2014. To this we can add an estimated R 15.5 billion $^{2}$ in subsistence or informal market production that is not taken into account in DAFF statistics (Aliber and Mdoda 2014). There are three broad areas of primary agricultural production: animal production (46 percent of gross value in 2013/ 2014), field crops (28 percent) and horticulture (26 percent). In line with the replication of the US national agricultural model in the era of state-led development, South Africa has a grain-livestock complex (GLC) at the heart of the agro-food system. Combined poultry (meat and eggs), maize, cattle and dairy constituted R 104.4 billion or 50 percent of the total value of commercial primary production in 2014. Beyond this, the GLC extends upstream, where animals purchased and animal feed alone had a combined value of $\mathrm{R}$ 54.2 billion in 2014; maize is the major commercial seed type, the sector uses a large share of fertiliser and machinery, etc. Downstream, the GLC extends into grain storage and handling, processing and further value addition, and also has numerous connections into other agricultural products (e.g. soya and molasses from sugar into animal feed).

While statistics on subsistence and smallholder agriculture are woefully inadequate, it is estimated that there were around 2.5 million households practising some kind of agriculture in 2013. Roughly 2.3 million of these were black households engaged in subsistence production (i.e. who farm for an extra or main source of food), and 167,00o were smallholder households (i.e. who farm for a main or extra source of income) (Aliber and Mdoda 2014, 1). To this we can add somewhere around 40,000 large-scale commercial producers, according to the 2007 Census of Agriculture (Stats SA 2010, 10). This was the last time a survey on commercial agriculture was conducted, and the information is hopelessly out of date. But even if the data is somewhat questionable, it is fairly evident that the numbers of commercial farmers have been declining since deregulation.

There appears to be some concentration in commercial agricultural production. Despite a decline in farmer numbers, the area under production has not shrunk to the same extent, indicating consolidation. Liebenberg $(2013,28)$ indicates just 0.6 percent of commercial farming units (237 units) accounted for a third of income in 2007. This can be compared with the top five percent of farms accounting for 10 percent of income in 1993. Also using 2007 Agricultural Census data, Kirsten (2011) indicated that 57 percent of commercial farmers had an annual gross income of $\mathrm{R} 500$ ooo or less, and just seven percent of all commercial farm units had a gross income of $\mathrm{R} 5$ million or more. Nevertheless, direct corporate ownership in agricultural production is not pronounced and, where it exists, is decidedly uneven. Corporate power in agricultural production expresses itself more in supply chain control than in direct production. There are particular locations where corporate producers are dominant, for example in cattle feedlots and poultry production. However, contract or open-market arrangements are more common, as these allow for a wider supply base that mitigates the production risk for large buyers. Individual farmers or farmer partnerships may be very powerful in local areas or regions, though they are less so on a

\footnotetext{
${ }^{2}$ Estimated R 13 billion in 2010/2011, increased by six percent per year for a 2013/2014 figure.
} 
national scale, with some exceptions (e.g. ZZ2 in vegetables, or wine farmers). More detail requires commodity-specific analysis.

Increasing economies of scale are a driving force in commercial agriculture. Deregulation and trade liberalisation opened the space for global competitors who either have lower cost structures or can rely on government subsidies to land their products cheaper than local producer costs. According to Bernstein $(2013,26)$, the largest enterprises are generally in areas of high agricultural productivity, and are major field crop producers, irrigated and export-oriented horticulture enterprises or intensive livestock enterprises. Most operate on more than one non-contiguous farm and sometimes on rented land too.

The result is growing differentiation amongst commercial farmers and the deployment of a range of strategies of diversification and consolidation, including buying or renting more land, diversifying operations on their present property, exploring different markets in search of higher product prices, seeking to enlarge income and cost margins by improving productivity and increasing yields, and movement up the value chain (Genis 2015). Other trends are towards part-time production, and diversification into other economic activities alongside agricultural production.

Aggregation and primary processing are intermediate between primary agricultural production and downstream nodes in chains. This is commodity specific and is best dealt with in commodity analyses. There is concentrated activity specifically in feedlots for cattle, grain storage and handling in grains, and grading and packing in horticulture. These are activities that are performed on the farm or in the farming area. In livestock, 75 percent of cattle go through concentrated feedlots before reaching the market. These feedlots are dominated by a core of large producers, including Karan Beef, Bull Brand/Kolosus, EAC Group and Sparta Beef, which among them had a 54 percent market share in 2010 (Spies 2011, 82). Kanhym Estates is dominant in pig feedlots. Vertically integrated poultry producers include Astral Foods, Rainbow (RCL Foods), Afgri, Country Bird, Quantum Foods and Sovereign Foods.

In grain storage and handling, 17 large owners held 94 percent of the silo market, and Senwes, Afgri and NWK had 74 percent of grain silo capacity in 2011 (DAFF 2012b). Senwes has around 25 percent of commercial storage capacity, and handles approximately 20 percent of the country's grain and oilseeds (Senwes 2015), and nearly 30 percent of all grain (Senwes 2014, 7). Afgri had an approximate 25 percent silo market share at the time of its acquisition by AgriGroupe (Competition Tribunal 2014, 5). No systematic work has been done to date on mapping out preliminary processing and packing in horticulture. Facilities tend to be decentralised under the control of local farmer partnerships, rather than national-scale agribusiness control. There may be some commodity-specific concentration, for example ZZ2 in tomatoes. 


\section{Food manufacturing}

The focus here is specifically on food manufacturing rather than broader agro-processing. DAFF divides agro-processing into 11 sub-divisions. ${ }^{3}$ Food (42 percent) and beverages (12 percent) are the two largest sub-divisions within agro-processing (DAFF 2012a, 5). By DAFF's figures, food constituted an average of around 12 percent of the total value of manufacturing in South Africa between 2006 and 2010, showing a slight but not major declining share of total manufacturing since the mid-1980s.

Stats SA valued food and beverage manufacturing sales at R 391.9 billion in 2014: beverages, $R$ 107.2 billion (27 percent); 'meat, fish, fruit etc.', R 105 billion (27 percent); grain mill products, R 64.1 billion (16.4 percent); dairy, R 34 billion (8.7 percent); and other food products, R 81.6 billion (20.8 percent) (Stats SA 2015a, 11). The packaged food market was valued at R 172.4 billion in 2014 (Euromonitor 2015e). This is about 44 percent of the total food and beverage market. South Africa had a positive trade balance in processed food in 2014 .

Deregulation in the 1990 os led to increasing processing opportunities especially in baking, dairy, milling and meat production (Mather 2005, 611), but income has remained very concentrated. Deregulation has simultaneously led to a decline in employment in agroprocessing and food manufacturing. Employment in food manufacturing dropped from an annual average of 230,000 (1996-2000) to 186,000 (2006-2010), a 19 percent decline (DAFF 2012a, 11-12).

The focus in this contribution is on general food manufacturers and excludes beverages and commodity-specific food manufacturers, especially in sugar, dairy and poultry, where large corporations are also dominant. These should be the subject of commodity-specific analyses. In 2011, sugar, fish and beverages were the most concentrated sectors, followed closely by oils and fats, grain mill products and starches, and bakery products. In each of these sectors, the five largest companies had a combined formal market share of 75 percent or more (Stats SA 2011, 23).

The largest listed general food manufacturers are Tiger Brands, with a market capitalisation of R 58.7 billion in 2014; Pioneer Foods at R 41.3 billion; AVI at R 28.6 billion; and RCL Foods at R 16 billion (Financial Mail 2015a). Alongside these are the two largest non-South African multinationals, Nestlé and Unilever. Both have larger operations in South Africa than RCL Foods, which incorporates Foodcorp, a general food manufacturer, along with Rainbow Chicken and TSB in sugar production. Premier Foods is also a smaller general food manufacturer that was acquired by Brait and delisted in 2011. Among them, Tiger Brands, Premier Foods and Pioneer Foods accounted for 60 percent of white maize milling in 2013 (ACB 2013, 17).

\footnotetext{
${ }^{3}$ These are: food, beverages, paper and paper products, wood and wood products, textiles, wearing apparel, furniture, tobacco, rubber products, footwear, and leather and leather products.
} 
According to Euromonitor, the top five packaged food manufacturers held 34.3 percent of the packaged food market in 2014; however, this excludes maize and sugar. There is also some question about how Euromonitor arrived at their statistics. In particular, the figure for Tiger Brands packaged food sales that Euromonitor gives is the same as the figure Tiger Brands gives in its 2014 annual report for total turnover, including all non-food operations and maize products. The company indicates that just 30 percent of its revenue comes from consumer food products, which would significantly reduce Tiger Brand's market share to around 5.2 percent of the packaged food market. This is about the same share as Pioneer Foods. This seems more realistic because the companies had similar revenues from their respective food businesses in 2014 ( $\mathrm{R} 18.9$ billion for Tiger Brands and R 17.7 billion for Pioneer Foods). Regardless of these details, the largest corporations are Tiger Brands, Pioneer Foods, Nestlé, AVI and Unilever.

According to the information from annual reports and websites, the top five general food manufacturers in South Africa had food revenues of approximately R 57.8 billion in 2014, which is only around 14 percent of the total market, according to figures from Stats SA (2015a). This amount includes some logistics performed in-house or even as commercial operations for other clients, as well as some beverages. This appears to be a relatively low market share but excludes commodity-specific lines, especially sugar, dairy, poultry and fish, which have their own dominant corporations. Retailers have also encroached into the manufacturing space through private labels, although products may still be manufactured by the big food corporations. In addition, many of the estimated more than 4000 food production companies (Madima 2006) will produce intermediate goods that find a market amongst the big corporations. Madima says the top 10 corporations account for 70 percent of total turnover, which does not match the figures above. However, this probably refers to turnover of Johannesburg Stock Exchange (JSE) listed companies, since Madima also shows market concentration on the JSE, so this may be his frame of reference.

This low percentage share for the large corporations seems counter-intuitive given their ubiquity in everyday life, and begs the question of who is producing all the rest. However, these figures come from the corporations themselves and are matched to official government data on size of the overall sector. More work needs to be done on quantifying and revealing the key features of the food manufacturing periphery to make sense of this.

\section{Wholesale and retail}

The value of the total food wholesale and retail market was estimated at $\mathrm{R} 519.4$ billion in 2014 in a report for the United States Department of Agriculture (Ogando 2014). 'Traditional' grocery retailers and independent small grocer sales were valued at R 291.5 billion ( 56 percent), and 'modern' food retail sales (mainly supermarkets, but also hypermarkets, convenience stores and discounters) were valued at R 227.9 billion (44 percent) (Figure 2; Appendix 1). This unexpected finding is discussed further below. There are some limitations in the available data which make it difficult to segregate wholesale from retail. The two main corporate food wholesalers are Massmart and Spar. These corporations operate different models. Massmart operates wholesale divisions that service the non- 
corporate 'periphery' (see below), but in recent times - especially leading up to and following the Walmart acquisition - also entering into the food retail space with a combination of food sections in Game stores and the creation of wholesale-retail hybrids such as Cambridge stores, which service small, 'informal' food distributors as well as retail to the consumer. Spar is a wholesaler that provides goods and services to franchises bearing the corporate brand. In both cases, the data (whether the United States Department of Agriculture or Euromonitor) is not disaggregated. For this reason, wholesale and retail have been combined into one category. Double counting could conceivably be an issue, especially for Massmart and 'informal'-sector retailers, but it is also possible that the data only indicates value added by informal-sector retailers on top of the wholesale of Massmart's offerings.

\section{The broad periphery}

The broad periphery is defined here in the same way as Euromonitor's 'traditional' markets (small grocers, spaza shops, street traders, etc.), also known generally as the informal sector, though it shades into the formal, especially with the small grocers. The use of the term 'periphery' is somewhat problematic because it refers to a large number of economic actors. However, it is used more in the sense of the distribution of power, where a corporate core has concentrated economic and political power while the economic and political power of the large number of economic actors outside this core is dispersed and weak. Ogando (2014) indicates a 56 percent share of the total food market for this 'traditional' retail sector, a larger share than that of 'modern' retailers. It is difficult to compare this directly with Euromonitor data we have at hand, because Euromonitor splits retail into a number of categories - grocery retailers and mixed retailers are most relevant for food - without distinguishing between food and non-food products as discussed below. Euromonitor data (2015a) says 46 percent of the grocery retail market is through traditional grocery retailers ( $R$ 216.8 billion), but that doesn't include mixed retailers. For mixed retailers, no 'traditional' share is indicated but there are many hybrid forms, including warehouse clubs and mass merchandisers that blur the boundaries (Euromonitor 2015b).

Whichever way we look at it, even a 46 percent market share for non-corporate actors is very significant and warrants further attention. Currently, this sector is treated as secondary in policy and is often considered a backward system in need of modernisation. But even in the face of seemingly rampant corporations, this diversity of distribution remains a central feature of the agro-food system. The idea that in aggregate the informal or small could be similar to, or even larger than, the formal in monetary terms is very significant because it suggests that while corporate wholesalers and retailers have concentrated market power, exercised in ways that go beyond just direct market share, there is also a wide base of economic activity beyond the corporations. Corporations are aware of this periphery and have moved aggressively into this space in the past two decades. Massmart, for example, has explicitly identified small independent retailers as a competitive threat (Massmart 2014, 17). 
Euromonitor (2015a) indicates more than 81,00o outlets outside the 'modern' (mainly supermarket) sector. Outlets incorporate both formal and informal channels for the 'retail' distribution of food to consumers. Earlier studies estimated 400,000 hawkers/spaza shops in the mid-200os (Ligthelm 2006a), which obviously can't refer to the same categories because it is five times the amount estimated by Euromonitor. This would place the number of street traders and spaza shops at hundreds or even thousands per district, playing a critical role in distributing food where it is needed, even if they often are a conduit for corporate products, too. Wills $(2009,3)$ estimated 500,000 street vendors were active in 2007, of whom 72 percent were women. According to the Wholesale and Retail Sector Education and Training Authority (W\&RSETA 2011, 5) some reasons consumers shop at smaller outlets include location/convenience, price, speciality products, customer service, clean stores and knowledge/expertise. Most people access food from both the formal and informal systems, so these are complementary rather than exclusive (Crush and Frayne 2010). The 'relatively high density of informal and independent food retail channels contribute to a field of choice' (Aliber and Mdoda 2014) for poor consumers.

Euromonitor (2015c) calculated total retail employment of 1.11 million in 2014. The big five corporate retailers combined employed around 285,0004 people in all operations (including outside South Africa) in 2014, based on information in annual reports. This reveals an estimated minimum 825,000 people working outside this corporate core in South Africa (some of the corporate employment is outside South Africa). Earlier studies estimated employment generated by hawkers at around 415,000 and spaza shops around 320,300 (Ligthelm 2006b, 45). These various figures suggest the ongoing importance of this socalled 'informal' sector, which is underestimated in policy and channelling of support.

However, the actors in this periphery are fragmented, unlike corporate retail where the actors are large, consolidated and centralised units that can exert much more direct influence over the market through deliberate action. Smaller retailers face difficulties in competing with modern grocery retailers, including franchises, and could be forced into niche markets to survive. Alternatively, they could constitute an additional outlet for corporate products and processes, i.e. incorporation into/extension of corporate value chains. This is a role they already play to some extent. The Competition Commission (2015) argues that shopping centre development has caused a decrease in the number of small, informal and independent retailers, and a decline in their profits and profitability $(2015,3)$. The Commission argues that this is likely to have an adverse effect on employment, income levels and the spread of ownership (2015, 4), and has launched an inquiry on this. Despite these threats it is expected that traditional grocery retailers will continue to be a key channel in South Africa's retail environment, especially township markets (Euromonitor 2015c, 19).

\section{The corporate core}

The terms 'grocery retailers', 'modern retail' and the like are derived from Euromonitor, on whose data we rely. Euromonitor (2015a) indicates a 'modern retail' share of 54 percent

\footnotetext{
${ }^{4}$ Including franchises for Pick n Pay but excluding franchises for Spar.
} 
of the 'grocery retail' market, noting this excludes other retailer categories. Spaza shops and other small and informal distribution outlets are incorporated into the definition of grocery retailers, though the extent is not clear. Corporate retailers in the grocery retail category are Shoprite, Pick n Pay and Spar. It is taken that these are primarily but not exclusively food and non-food grocery products. But grocery retail is not the only channel through which food commodities are exchanged. There are also mixed retailers - including Massmart and Woolworths, in Euromonitor's categorisation - who sell groceries alongside a significant portion of other products (e.g. homeware, apparel, electronics, furniture and financial services). Mixed retailers incorporate warehouse clubs (and hence a wholesale element), mass merchandisers, variety stores and department stores. So in the data the markets and channels are separated out but the food components of each are not.

Modern food retail (which is taken to incorporate both large grocery and mixed retailers/wholesalers) was valued at R 227.9 billion in 2014, or 44 percent of the total market. Supermarkets constituted 80 percent of this value, with the rest divided among hypermarkets, convenience stores and discounters (Ogando 2014). According to Retailer News (2015), fresh produce constituted around 36 percent of total food retail, dry goods around 30 percent, beverages 20 percent and perishables 14 percent.

The five big food retailers in South Africa are also the five largest retailers across all sectors: in order, Shoprite, Pick n Pay, Spar, Massmart and Woolworths. Among them they hold a third of the total retail market (food and non-food) (Euromonitor 2015c). In 2014 Shoprite had a market capitalisation of R 94.1 billion; Woolworths, R 87.5 billion; Pick n Pay Stores plus Pick n Pay Holdings, R 35.5 billion; Spar, R 32.7 billion; and Massmart, R 29.9 billion. This reflects the capitalisation of each entire company including non-food and offshore operations, and not only their food business. Specifically food business data is not provided in annual reports or other public sources.

The big five food retailers had a combined profit (including but not limited to food) of R 14.5 billion in 2014. This is almost three times the profit of the top five food manufacturers. Followup work will need to include identifying how profit is constructed and reported, because it definitely excludes large management salaries and options, as well as corporate facilities, buildings, perks, etc., all of which run into the billions. Profits also refer only to that which is declared in South Africa.

Retailers are under pressure, especially from shareholders, to increase returns. Economies of scale are the order of the day for the mass market. The sector is very competitive, with ongoing product and process innovations, together with suppliers, in a continuous quest for efficiency and cost savings, and in-store design and formatting innovations being adopted to find a competitive advantage. Key trends in food retail include product diversification beyond groceries; multi-channel approaches to reaching consumers; in-store financial services, including the distribution of social grants; larger format stores, including hypermarkets and mall expansion; format diversification, such as forecourts and convenience stores; and 
mining of customer data (gathered, for example, through loyalty programmes and datasharing agreements) to shape supply and demand.

Woolworths $(2014,86)$ indicates a trend in its own operations towards fewer, more strategic food suppliers, many with exclusivity arrangements for private-label products. Euro-monitor (2015e, 38) notes private label penetration of packaged food. A few years ago, private labels stood at around 12-15 percent of market share, and are an increasingly significant player in the retail space (SGE 2013, 33). Expansion of private label products allows retailers to take control of branding, a profit centre in the era of intellectual property rights.

\section{Food service and other channels to the consumer}

Food service refers to food prepared outside the home that may be consumed at home or outside the home. It includes consumer food service that is direct to consumer - restaurants, fast food, street foods, hospitality (hotels, etc.); and institutional food service, which involves companies that prepare food for sale via an intermediary, e.g. hospitality, public institutions (schools, hospitals, prisons, military, etc.), canteens and other catering operations for the public and private sectors, and others.

Consumer food service has many sub-categories, ranging from full-service restaurants through to street stalls/kiosks (Euromonitor 2015d). Total sales came to R 78.3 billion in 2014 (Euromonitor 2015d, 4), of which food was 72 percent and beverages was 28 percent. For comparison this is equivalent to about 15 percent of the total food wholesale and retail market. Two-thirds of consumer food service sales were from stand-alone outlets, and 20 percent of sales were from outlets in retail locations, like shopping centres and malls (Euromonitor 2015d, 6). There were a total of 115,529 units/outlets in 2014, and just 7.6 percent of these were chain outlets. Of the 106,772 independent outlets, around three quarters $(78,889)$ were street stalls/kiosks (Euromonitor 2015d, 5). This market is growing on the back of increasingly time-constrained consumers, who are doing less home cooking and are seeking convenient 'meal solutions' and 'value-for-money' (cheaper) offerings (Euromonitor 2015d, 3).

Despite the large number of outlets, the top three corporations operating in consumer food service - Yum! Brands (KFC), Spur Corp (Spur, Panarotti's, John Dory's and others) and Famous Brands (Wimpy, Steer's, Debonair's and others) - had sales of R 38 billion, or 48.5 percent of market share in 2014. Together with Nando's and McDonald's, the top five corporations had a 61.2 percent share of the market. Chain operators are driving the market, and the recent licensing of US multinational brands Burger King and Domino's Pizza by domestic companies signals expansion. This is a fast-growing market with significant negative implications for nutrition and health (Igumbor et al. 2012; Thow et al. 2015).

The institutional/service sector includes transport services, health (public and private hospitals), educational institutions and prisons. This is a primary target for public sector procurement from black-owned and -controlled supplier businesses, but was 
valued at a surprisingly small USD 71 million (approximately $\mathrm{R} 750$ million in 2013) (Ntloedibe 2015, 8).

'Meal solutions' is a growing category, with a wide range of products from canned and frozen products to ready meals. Tiger Brands was the market leader in meal solutions, and Woolworth's private label was the top brand in 2014 (Euromonitor 2015e). Bidvest Foodservice constituted 54.7 percent of Bidvest's total turnover in 2014, but only 6.5 percent of this was in southern Africa, including South Africa, and the rest was in Asia Pacific and Europe (Bidvest 2014). Retailers and manufacturers, including Checkers (Shoprite), Unilever, Tiger Brands and others, have established dedicated food service divisions.

\section{Corporate power and the consumer food environment}

The CFE essentially refers to the environment in which consumers make choices and decisions about food. Many social, psychological, physiological, cultural and economic factors shape the choices people make about what to eat (Claasen, Covic, and van der Hoeven 2016). One consequence of modernisation and capitalist expansion is a nutrition transition (Popkin 1993; Igumbor et al. 2012) away from diets high in cereal and fibre and towards diets high in sugar, fat and salt, which produce the greatest allure for the lowest possible cost (Moss 2013; Mountford 2015).

These trends are apparent in South Africa (Steyn 2006; Igumbor et al. 2012). Obesity is growing alongside continued nutritional deficiencies in South Africa. There is a steady increase in per-capita food supply of fat, protein and total calories, with salt intake in excess of recommended levels. This is linked to changes in dietary patterns as wealth increases, with increases in the sales of packaged foods (Igumbor et al. 2012, 1). The largest increases in the consumption of sugar and sweeteners are through processed foods (Ronquest-Ross, Vink, and Sigge 2015). Accumulated losses to South Africa's gross domestic product (GDP) between 2006 and 2015 from diabetes, stroke and coronary heart disease alone were estimated to cost USD 1.9 billion, according to Prof. Karen Hofman at Wits University Department of Public Health (Mountford 2015, 2).

Rising obesity rates and food-related non-communicable diseases present a complication for food corporations, since research implicates their products as a cause of many modern diseases. Shareholder return is a major driver in leading corporations to formulating the cheapest products, with innovation focused on developing products that are cheap and easy to manipulate. Corporations make their profits off processed products through economies of scale and controlling the production process down to a very detailed level. Packaged foods are very profitable but would not be as appealing without the high amounts of added sugar, flavourants and salt (Mountford 2015, 1).

Breakfast cereal is an example of product formulation and innovation that converts cheap, readily available bulk commodities (grain, sugar) into premium products with large profits. The production process has been reduced to a set of standardised inputs that can be micro-adjusted as required to meet anticipated market demand. Products high in salt, 
sugar and fat contents are easy and cheap to produce and are desired by consumers. Nutrient inputs are volume controlled. There is a standardised base product that can be tweaked to meet regulatory demands and consumer fads alike. In such conditions, corporations may be able to adapt products to respond to consumer trends or fads for healthier food by increasing (synthetic) micro-nutrient inputs, or decreasing sugar or salt content, for example, without really changing the product at all. This suggests that consumer activism could result in some improvements in food content, but on the other hand, it does nothing whatsoever to challenge corporate power.

Behind the scenes, food technology and product innovation is big business. The South African Association for Food Science and Technology (SAAFoST) 5 is a national association of food technology professionals with about 2000 members, including institutional membership by many of the largest agro-food corporations. Another body that deals with product formulation and innovation is the International Life Sciences Institute (ILSI) South Africa, which presents its mission as improved nutrition and food safety. ILSI's decision-making body is composed of Bayer CropScience, Coca Cola, Kellogg, Monsanto, Unilever, Clover, DSM Nutritional Products, Mars Africa and Nestlé South Africa (ILSI 2016). Apparently neutral food technologies are developed and deployed in the interests of corporate profitability.

Apart from product formulation and innovation, corporations also pursue other efforts to increase the demand for cheap, easily manipulated products. Advertising, including to children, is the most obvious method for altering consumer perceptions of products with poor nutritional value. Food and beverage companies were the top four advertisers in South Africa in the first half of 2014 (Unilever, Shoprite, Pick n Pay and SABMiller), and were 12 of the top 50 advertisers (Financial Mail 2014, 59). Manufacturers and retailers collaborate on sales promotions and packaging to give the impression of a healthy product (Igumbor et al. 2012, 5).

Corporate strategies to alter the CFE include increasing the availability of processed foods through supermarket expansion into lower income areas; the use of informal channels; aggressive expansion by fast food chains; and increasing affordability, especially through corporate economies of scale and supply chain efficiencies (Igumbor et al. 2012, 4). Healthier food products that are more readily available through supermarkets are typically 10-60 percent more expensive than less healthy foods by weight, and 30-110 percent more by cost of food energy. Refined cereal and foods with added sugar and fat are amongst the lowest cost sources of energy, while nutrient-dense foods (e.g. lean meats, fish, fruit and vegetables) cost far more (Igumbor et al. 2012, 4).

Corporate influence on dietary guidelines is another area of demand construction. The state plays a coordinating role in regulating basic food nutrition, but under the influence of scientific advisors, many of whom are located in corporations. Corporate influence is

${ }^{5}$ http://www.saafost.org.za 
expressed through PPPs, sponsorship of and association with dieticians' associations and a range of other institutions that influence government policy, including SAAFoST, the Association of Dieticians of South Africa (ADSA) and the Nutrition Society of South Africa (NSSA). SAAFoST sits on the Food Legislation Advisory Group in the Department of Health (DoH) and launched the Food Advisory Consumer Service in 1995 to provide 'factually/scientifically correct information on food issues' together with ADSA, the DoH and the South African National Consumer Union (FACS 2016). The Consumer Goods Council of South Africa, whose members are retailers, wholesalers and manufacturers of consumer goods, has a Food Safety Initiative (CGCSA 2016) where it claims to offer 'objective, independent scientific advice' and assistance in terms of related legislation. It has made inputs on food ingredients, the South African Food-Based Dietary Guidelines and the South African Food Guide. While such partnerships between government, consumer representatives and food producers could be beneficial, in their current structure they are driven by corporate interests.

ADSA influences government food policy, with ties to food corporations. ADSA spon de Sea Harvest, Huletts Sugar (EquiSweet), Kellogg's, Pick n Pay, DSM, Woolworths, Nativa, Unilever, Parmalat, Pronutro and Health Connection (Mountford 2015, 3). It has diamond, silver, gold and platinum sponsors, with diamond status costing R 64,000 in 2014. The ADSA president, membership relations manager, and communications manager were all staff of Kellogg's in 2014 (Mountford 2015, 4). ADSA and NSSA provide a veneer of scientific neutrality to the branding of 'healthy' foods - for example, 'health bars' - even though these have very high sugar content. Another example of corporate influence on the CFE is through 'health by association', e.g. Kellogg's sponsorship of the NSSA's 2014 Nutritional Congress and ADSA, or the training of nutrition professionals (Mountford 2015, 2). This legitimisation of food companies as global health experts is fuelled by a growing number of PPPs with public health organisations. Food companies are rebranding themselves as nutrition companies, asserting authority not only over food production but also malnutrition, obesity and even poverty (Mountford 2015, 3).

Corporate nutrition, health and wellness initiatives are another way in which corporations seek to take control of trends in the population towards healthier food. All the major manufacturers have their own nutrition, health and wellness initiatives; for example, Tiger Brands' Eat Well, Live Well initiative works with the Nutrition Information Centre at University of Stellenbosch to offer guideline daily amounts (GDAs). Tiger Brands Foundation supports an in-school breakfast feeding programme with the Department of Basic Education (Tiger Brands 2014, 121). Coca Cola's Beverage Institute for Health and Wellness in Southern Africa (Beverage Institute 2016) claims to be 'a resource for health professionals on the science of beverages, hydration and active healthy living'. It is based on poor argumentation that says all calories are equal so therefore it doesn't matter what food you eat; it is only the amount that matters. This is easily countered with the example of refined sugar being high in calories (energy) but low in nutrients compared with other foods. Such corporate initiatives indicate a privatisation of health standards and attempts to impose a private sector authority in the field of health and nutrition (An et al. 2013). 
Under pressure from public health advocates, in particular, government has introduced draft regulations to reduce sodium content in processed food; regulations limiting transfats were applicable from 2011; and there are efforts to regulate sugar content (Steyn, Myburgh, and Nel 2003; SGE 2013, 18). So far these efforts have been fairly weak, with some work on product labelling, marketing to children and product reformulation. In February 2016 the Minister of Finance announced a tax on sugar to be levied with effect from April 2017, which could have positive nutritional benefits (Teagle 2016). Nutritional labelling remains voluntary unless a claim is made, and there is a standard format for labelling and requirements for use of certain terms (e.g. 'high in', 'free of'). Voluntary GDA labelling is used by a number of big organisations (Igumbor et al. 2012, 5). Nutritional claims must be supported by an analysis done on the product by a reputable laboratory accredited by the South African National Accreditation System (SANAS), following procedures set out in regulations, and endorsements can only be granted by an organisation run by professionals (SGE 2013, 17). As indicated, though, the neutrality of professional organisations may be compromised by corporate sponsorship and influence. In 2007, draft guidelines were developed to prohibit advertising of non-essential foodstuffs to children under 16, but these were shelved. Companies responded with a voluntary pledge with limited scope, without specific commitments, and no monitoring reports have been released (Igumbor et al. 2012, 6).

\section{Trends and dynamics in the agro-food system \\ Financialisation and institutional ownership}

Analysis of the role of finance capital and financialisation in the South African agro-food system is in its infancy. The only published work, by Ducastel and Anseeuw (2015), starts the process of looking at ways in which farmland and agricultural assets are converted into financial assets. In South Africa the growing role of financial capital in the agro-food system is manifested in various ways, two of which are the institutionalisation of share ownership and the growth of agri-investment companies. The expansion of consumer credit, wider financial inclusion and the impacts on food markets require further research. The use of riskbased financial instruments, such as derivatives, securities and futures as a profit centre in productive entities requires analysis and monitoring. To date, it mostly appears these instruments are being used to hedge against commodity and currency volatility, rather than as profit centres in their own right, although more investigation is warranted.

Institutionalisation of share ownership refers to the rise to control of institutional shareholders, most significantly pension funds, but also including a range of other public and non-public vehicles. The Public Investment Corporation (PIC), whose primary mandate is to manage the funds of the Government Employee Pension Fund (GEPF), has approximately 13 percent of total market capitalisation on the JSE (PIC 2015). It is the largest investment fund operating in South Africa, with assets under management at around $\mathrm{R} 1.6$ trillion in 2014 (PIC 2014, i). PIC/GEPF is a major share- holder in many of the largest corporations operating in the agro-food system (Figure 3). PIC/GEPF is often the largest single shareholder in a context where 15 percent may confer effective control. 
Another source of pensions is from within the corporations themselves. More analysis needs to be done to identify where worker pensions are being invested.

Needless to say, in both the public and private pension funds individual contributers do not have significant control over investment decisions, despite the value notionally being theirs. Contributers have very limited or no voice through their share ownership because their financial contributions are atomised before being aggregated under the control of an investment institution. Workers and consumers lack control or say over these vehicles, even when the funds are their own future pensions. Control is exerted from the top, through management and shareholders. Overall, some of the biggest South African agrofood corporations have institutions as their controlling shareholders. These include Tiger Brands, Pioneer Foods, AVI and Shoprite.

The last few years have witnessed the rise of agri-investment companies in South Africa. These JSE-listed companies buy shares in the agro-food system and elsewhere in the economy, domestically and globally, to construct an investment portfolio. Johann and Anton Rupert with Remgro and Jannie Mouton at PSG with controlling stakes in Zeder are part of the Stellenbosch-rooted Afrikaner business elite (Formby 2007). These investment vehicles have holdings in banks, as well as in productive entities. The Rupert family have widespread interests, including a Geneva-based luxury goods operation, Richemont. Apart from its food system investments (Figure 3), Remgro's other major investments are in FirstRand/Rand Merchant Bank, MediClinic and RMI. Apart from Zeder, PSG also has interests in Capitec Bank and investment funds. Christo Wiese, the Chair of Shoprite, has a large stake in Brait, which recently acquired and delisted Premier Foods. In 2014 he had significant holdings in resources group Pallinghurst, industrial services conglomerate Invicta and property hybrid Tradehold (Hasenfuss 2014).

Figure 3 shows the web these interests, together with the PIC, have woven through the agrofood system. Remgro's major agro-food interests are in RCL Foods (incorporating Foodcorp, Rainbow and TSB Sugar), Distell, Unilever South Africa and Grindrod (with stakes in Senwes and NWK). Zeder's main interest is in Pioneer Foods via Agri-Voedsel, then Capespan, Kaap-Agri and Zaad. The PIC holds the web together, linking Zeder and Remgro to Christo Wiese's agro-food interests in Shoprite and in Premier Foods via Brait.

A related issue tied to financialisation and institutionalisation is the globalised character of ownership, leading to a dissipation of domestic control. Examples are the acquisitions by Monsanto of Sensako and Carnia, two of South Africa's largest seed companies at the time, and the more recent acquisition of Pannar by Du Pont Pioneer Hi-Bred. In fertiliser, Kynoch is now owned by Export Trading Group, an MNC originating in Kenya. Afgri (formerly OTK), the largest agri-services and grain storage and handling corporation in South Africa, was delisted and is now owned by a Canadian-led private investment consortium called AgriGroupe. In sugar, Illovo is now a subsidiary of Associated British Foods, one of the largest sugar companies in the world. Massmart is majority owned by Walmart. And, most recently, SABMiller, currently one of the three largest corporations on the JSE (but, for 
some time, not majority owned by South African-based shareholders) has recently accepted a buyout offer from $A B$ Inbev. But even corporations still mainly owned by domestic shareholders may have large minority foreign shareholdings. Tiger Brands, for example, was 49.1 percent foreign owned in 2014 (Tiger Brands 2014, 253).

\section{The multinationalisation of South African agro-food capital}

There is some recent work on South African corporate agri-business expansion into Africa. In a comprehensive report ACB (2014) provided an overview across the agro-food system, looking especially at retailing, agro-processing, farming and inputs, with a focus on seed. Hall (2012) focused on organised commercial farmer expansion, as well as the expansion of sugar corporations Tongaat Hulett and Illovo into the region. Other research on sugar has followed (e.g. Dubb 2015; Martiniello 2015; Sulle 2015), showing further expansion and a shift in the location of value creation into the region.

Louw et al. (2008) found that increased consolidation and concentration of regional fresh produce markets were taking place. South African supermarkets were leading the charge, with centralised procurement strategies dominating. The authors also highlighted smallholder farmer exclusion from these regional chains, through both the demise of 'traditional' markets and the use of private standards that smallholders struggle to meet. Pardhun (2011) indicated further fragmentation of public fresh produce markets in Africa and their displacement by supermarkets, again with negative impacts on smallholder farmers who lose access to markets as a result. Campbell (2015) does show supermarket expansion, but questions its all-encompassing nature, indicating the ongoing resilience and importance of informal and open-air fresh produce markets, even when supermarkets are present (see also Wegerif 2014). This links to a whole field of research on informal food procurement and markets in Africa, with an expanding body of literature (e.g. Jayne et al. 2010; Battersby 2012; Wegerif 2014).

Africa is a natural outlet for numerous reasons, including fast-growing consumer markets driven by urbanisation and greater but more concentrated wealth, and similarities in the socio-cultural context for South African corporations. South Africa remains a core market but is saturated. According to AVI $(2014,46)$, for example, the fairly small domestic market reduces the attractiveness of major new investment in South Africa. Some companies like Bidvest or the sugar corporations have most of their operations outside South Africa. On the other hand, Shoprite, which has the biggest South African agro-food corporate footprint on the continent, still has over 80 percent of revenue from South African operations. Investing externally may also be a hedging strategy against exchange rate decline, and weakening governance and infrastructure in South Africa.

Figure 4 indicates the nodal expansion of South African agro-food corporations into the region. This is based on information in annual reports for the largest corporations in each node. Logistics leads the pack with 19 African countries hosting South African logistics operations. Wholesale and retail follows with 17 countries, then food manufacturing with 13 
and agricultural services with 11. These are followed by agricultural production and fertiliser (eight countries each), and grain/feed milling in four countries.

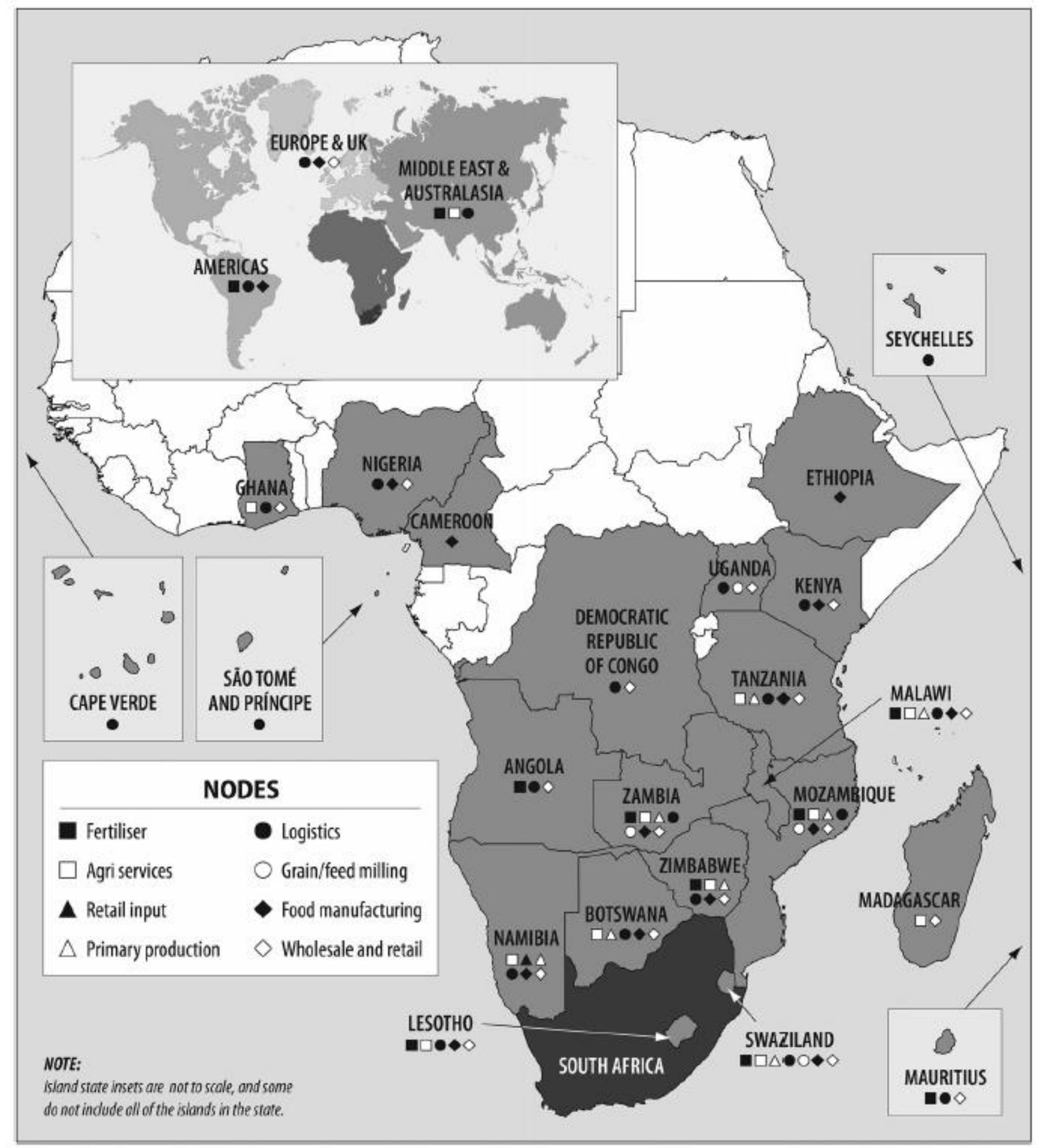

Figure 4. South African agro-food corporate expansion, 2014.

Note: Thanks to Dudu Coelho for assistance with the infographic.

Zambia has the most activity, with 21 corporations operating there in 2014, followed by Swaziland (19), Mozambique (15) and Botswana (14). Shoprite and Bidvest have a footprint in the largest number of countries in the region (14 each), followed by Barloworld (12), then 
Imperial, Massmart and Woolworths (11 each). Shoprite's African operations constituted 19 percent of group sales in 2014 (Financial Mail 2015a, 55). Bidvest got about 40 percent of its operating profits from outside South Africa in 2014 (Bidvest 2014, 20).

Food manufacturers and food service also distribute into additional countries, though they do not have physical production operations in these countries. Tiger Brands, for example, wholly owns Davita Trading, which exports Tiger Brands products to 33 countries in Africa, with Southern and West Africa the largest markets by value (Tiger Brands 2014, 43). According to the company, the route to market in sub-Saharan Africa remains largely informal, and reliance on local wholesalers and distributors to reach the final point of purchase remains critical to success (Tiger Brands 2014, 16). AVI $(2014,22)$ has a network of third-party distributors in countries where it does not have a direct presence. Pioneer Foods $(2014,8)$ has a relatively small direct footprint, but exports to 80 countries.

Challenges to regional expansion highlighted in recent times include lack of availability of suitable real estate, supply chain challenges, limitations on consumer spending in Africa, and an influx of new low-cost entrants, placing pressure on margins.

\section{Further research}

Areas for further research include:

1. The impact of food system change on food and nutritional security and livelihoods for poor and vulnerable people; agricultural input supply, logistics, agri-services, feedlots, grain handling and storage, horticulture sorting and packing, food manufacturing and consumer food service.

2. Retailer-supplier relationships and their role in competition in the wholesale and retail sector, and implications for small and independent retailers and livelihoods.

3. Mapping out the grain-livestock complex inter-linkages throughout the system, the livelihoods created and the power dynamics that shape the complex.

4. Focused research on specific commodities and on processed products as an increasingly consumed but problematic aspect of the food system in South Africa.

5. Work on livelihoods could focus on nodes with large peripheries to understand the dynamics, support needs, inter-relations between formal and informal, extent of corporate displacement and other impacts on local food geographies. More work needs to be done on consolidating information on the number of formal jobs and overall livelihoods created throughout the system.

6. Nutrition is a specialised area, but further work could focus on the impact of corporate concentration on nutrition, and more detailed investigation on product formulation and innovation, advertising, corporate influence on dietary and health advice and programmes, regulatory capture and the implications for the choice and quality of food consumers are offered.

\section{Conclusions}

The South African agro-food system has the characteristics of a corporate-led food regime, accompanied by economic concentration and centralisation of power, especially since 
deregulation in the early 1990s. Although there is an ongoing role for the state, the combination of greater corporate self-regulation and the multinationalisation of agro-food capital ensure a shift in the relationship towards greater corporate power. Characteristics of the contemporary regime include economies of scale, mergers and acquisitions, and concentration and centralisation of ownership and power.

However, power may be more widely distributed within the system than might be imagined. Each node in the system has a core, with a periphery varying in size and degree of integration with the core. Specific commodities have their own dominant actors. This suggests more distributed power within the system, with a number of large core operations with concentrated power but spread out throughout the system.

A key feature of the South African agro-food regime is the ongoing significance of a large periphery of economic actors in parts of the system. This is particularly the case in agricultural production, food retailing/distribution to the end consumer, and consumer food service. There may also be a fairly large periphery around transport, especially around agriculture, but more information is required. This periphery is significant, both in the numbers of people involved, which reach into the millions, and in the value created. Value in the periphery tends to be located mainly in food distribution. This highlights the key importance of understanding this sector in livelihood and job creation.

Corporate concentration appears to have been accompanied by a reduction in formal employment, especially in primary agriculture and in food manufacturing. While retail employment has grown in the past two decades, this was accompanied by casualisation and flexible work, low pay, questionable and incomplete health and safety, long and irregular hours, etc. (see Kenny 2001 for earlier work on retail and Visser and Ferrer 2015 for a recent update on similar processes in farm work). The large periphery in some nodes and declining formal employment suggest the need to investigate the livelihood-creation potential of this sector, and the trade-offs between the protection and strengthening of the periphery or the expansion of the corporate one. More investigation could be done on these peripheries to understand them better, and to identify what kind of support may be required that goes beyond trying to modernise these activities and convert them to formality as the default response.

The intensified role of finance capital in commodity circuits is expressed in institutionalisation of ownership and control and associated globalisation. Workers are implicated in ownership and investment through their pension funds, but without any collective power over these investments. Faceless corporations and processes are dominant. A related trend is towards the multinationalisation of South African agrofood capital, driven by economies of scale and higher returns on investment. These reflect a dissipation of ownership and control from national confines. The state continues to play a crucial and central role in regulating the system, but more as a creator of an 'enabling environment' for corporate activity than as a counter to such activity. This poses challenging 
questions for the nation state and possibilities for using the nation state to expand and improve livelihoods and nutrition alike.

At the same time as this concentration and centralisation are occurring, however, there is a large periphery, both in value and in number of productive actors. In primary agricultural production, retailing and distribution, and food service (prepared food) in particular, there are high levels of economic participation, even if much of this is marginalised from nodes of power. There are hundreds of thousands or millions of economic actors in these nodes. Strategies need to be developed for how to strengthen these actors and their systems rather than seeing them as obsolete hangovers from the past, destined for extinction.

\section{Acknowledgements}

Financial support from the South African National Research Foundation/Centre of Excellence in Food Security is gratefully acknowledged. Thanks to colleagues at PLAAS and the Centre of Excellence in Food Security, in particular Prof. Andries du Toit and Prof. Julian May, for comments and inputs, and thanks to the two anonymous reviewers for their comments. Thanks to Dudu Coelho for assistance with graphics, and to Rebecca Pointer and Liz Sparg for editing support.

\section{Disclosure statement}

No potential conflict of interest was reported by the author. 


\section{References}

Afgri. 2013. Integrated annual report 2013. http://static.globalreporting.org/reportpdfs/2013/ 4f52feb7e32ee3deo5aa197e18238444.pdf.

African Centre for Biosafety (ACB). 2009. Biotechnology, seed and agrochemicals: Global and South African industry structure and trends. Johannesburg: ACB.

African Centre for Biosafety (ACB). 2013. GM maize lessons for Africa: Cartels, collusion and control of South Africa's staple food. Johannesburg: ACB.

African Centre for Biosafety (ACB). 2014. Africa an El Dorado for South Africa's agribusiness giants. Johannesburg: ACB.

Aglietta, M., and A. Reberioux. 2005. Corporate governance adrift: A critique of shareholder value. Cheltenham: Edward Edgar.

Aliber, M., and L. Mdoda. 2014. The direct and indirect economic contribution of small-scale black agriculture in South Africa. Paper presented at the 2014 Annual Conference of the Agricultural Economics Association of South Africa, Mpekweni Beach Resort, Eastern Cape, 29 September-1 October.

Amin, N., and H. Bernstein. 1996. The role of agricultural co-operatives in agricultural and rural development. LAPC Policy Paper No 32. Johannesburg: Land and Agricultural Policy Centre (LAPC).

An, R., D. Patel, D. Segal, and R. Sturm. 2013. Eating better for less: A national discount program for healthy food purchases in South Africa. American Journal of Health Behavior 37, no. 1: 56-61.

AVI. 2014. Integrated annual report 2014. http://www.avi.co.za/investors/presentations.

Battersby, J. 2012. Beyond the food desert: Finding ways to speak about urban food security in South Africa. Geografiska Annaler: Series B, Human Geography 94, no. 2: 141-59.

Bayley, B. 2000. A revolution in the market: The deregulation of South African agriculture. Oxford: Oxford Policy Management.

Bernstein, H. 2013. Commercial agriculture in South Africa since 1994: 'Natural, simply capitalism'. Journal of Agrarian Change 13, no. 1: 23-46.

Beverage Institute. 2016. About us. http://www.beverageinstitute.co.za/.

Bidvest. 2014. Annual integrated report 2014. http://bidvest.com/ar/bidvest_ar2014/index.php. Burch, D., and G. Lawrence. 2009. Towards a third food regime: Behind the transformation. Agriculture and Human Values 26: 267-79.

Busch, L. 2010. Can fairy tales come true? The surprising story of neoliberalism and world agriculture. Sociologia Ruralis 50, no. 40: 331-51.

Campbell, M. 2015. The supermarket revolution: Gauging the transformation of food retail in the Southern African region. Paper presented at 'Rural transformations and food systems: The BRICS and agrarian change in the global South' conference, Cape Town, 20-21 April 2015.

Castells, M. 1996. The information age: Economy, society and culture. Volume I: The rise of the network society. Oxford/Massachusetts: Blackwell.

Claasen, N., N. Covic, and M. van der Hoeven. 2016. Food environments, health and nutrition in South Africa: Mapping the research and policy terrain. PLAAS Working Paper (forthcoming). 
Competition Commission. 2015. Grocery retail sector market enquiry terms of reference. Government Gazette No. 38863, 12 June 2015, Notice 580 of 2015. Pretoria: Competition Commission.

Competition Tribunal. 2009. In the matter between competition commission of South Africa and Sasol Chemical Industries (Pty) Ltd. Case No. 31/CR/Mayo5. Pretoria: Competition Tribunal.

Competition Tribunal. 2014. In the matter between AgriGroupe Holdings (Pty) Ltd and Afgri Ltd, Case No.017939. Pretoria: Competition Tribunal.

Consumer Goods Council of South Africa (CGCSA). 2016. About FSI. www.cgesa.co.za/fsi/about.

Council for Scientific and Industrial Research (CSIR). 2013. 10th annual state of logistics survey for South Africa. http://www.csir.co.za/sol/docs/10th_SoL_Bold_Steps_Forward_web.pdf.

Cousins, B. 2013. Smallholder irrigation scemes, agrarian reform and 'accumulation from above and below' in South Africa. Journal of Agrarian Change 13, no. 1: 116-39.

Crush, J., and B. Frayne. 2010. Pathways to insecurity: Urban food supply and access in Southern African cities. Urban Food Security Series No 3. Cape Town: African Food Security Urban Network (AFSUN).

Department of Agriculture, Forestry and Fisheries (DAFF). 2012a. Economic profile of the agro-processing industry in South Africa: 1970-2010. DAFF: Pretoria.

Department of Agriculture, Forestry and Fisheries (DAFF). 2012b. Maize market value chain profile. DAFF: Pretoria.

Department of Agriculture, Forestry and Fisheries (DAFF). 2015. Abstract of agricultural statistics 2015. Pretoria: DAFF.

Department of Trade and Industry (DTI). 2015. South African trade statistics. http://tradestats.thedti. gov.za/TableViewer/tableView.aspx.

Dubb, A. 2015. The logic of accumulation in Southern African sugar production. Paper presented at 'Rural transformations and food systems: The BRICS and agrarian change in the global South' conference, Cape Town, 20-21 April 2015.

Ducastel, A., and W. Anseeuw. 2015. Agriculture as an asset class: Financialisation of the (South) African farming sector. Paper presented at 'Rural transformations and food systems: The BRICS and agrarian change in the global South' conference, Cape Town, 20-21 April 2015.

Euromonitor. 2015a. Grocery retailers in South Africa: Category briefing. 8 May, Euromonitor. http:// www.euromonitor.com/.

Euromonitor. 2015b. Mixed retailers in South Africa: Category briefing. 8 May, Euromonitor. http:// www.euromonitor.com/.

Euromonitor. 2015c. Retailing in South Africa: Industry overview. 8 May, Euromonitor. http://www. euromonitor.com/.

Euromonitor. 2015d. Consumer foodservice in South Africa: Industry overview. 25 June, Euromonitor. http://www.euromonitor.com/.

Euromonitor. 2015e. Packaged food in South Africa: Industry overview. 10 February, Euromonitor. http://www.euromonitor.com/. 
Financial Mail. 2014. AdFocus 2014. Johannesburg: Times Media. Financial Mail. 2015a. Top companies 2015. Johannesburg: Times Media.

Financial Mail. 2015b. The property handbook 2015. Johannesburg: Times Media.

Food Advisory Consumer Service (FACS). 2016. What is FACS? www.foodfacts.org.za. Formby, H. 2007. Money manne. Financial Mail 30 March, 32-39.

Genis, A. 2015. Accumulation and differentiation: The dynamics of change in the large-scale commercial farming sector of South Africa. PhD thesis, Institute for Poverty, Land and Agrarian Studies (PLAAS), University of the Western Cape.

Greenberg, S. 2010. Status report on land and agricultural policy in South Africa, 2010. PLAAS Research Report 40. Bellville: PLAAS.

Hall, R. 2012. The next Great Trek? South African commercial farmers move north. The Journal of Peasant Studies 39, no. 3: 823-843.

Hasenfuss, M. 2014. Investment companies: Go big or go home. Financial Mail, 18-24 Sept, 42-43.

Igumbor, E., D. Sanders, T. Puoane, L. Tsolekile, C. Schwarz, C. Purdy, R. Swart, S. Durao, and C. Hawkes. 2012. "Big food," the consumer food environment, health, and the policy response in South Africa. PLoS Medicine 9, no. 7: e1001253.

Imperial Holdings. 2014. Integrated annual report 2014. http://www.imperialreports.co.za/reports/ ar_2014/integrated/pdf/full-integrated.pdf.

International Life Sciences Institute (ILSI) South Africa. 2016. About us: Members and leadership. http://ilsi.org.za/about-us/.

Jayne, T.S., N. Mason, R. Myers, J. Ferris, D. Mather, N. Sitko, M. Beaver, N. Lenski, A. Chapoto, and D. Boughton. 2010. Patterns and trends in food staples markets in Eastern and Southern Africa: Toward the identification of priority investments and strategies for developing markets and promoting smallholder productivity growth. MSU International Development Working Paper No. 104. Michigan: Michigan State University.

KAP Industrial. 2014. Integrated annual report 2014. http://www.kap.co.za/wpcontent/uploads/2014/10/KAP-IR-2014_IAR_web.pdf.

Kaplinsky, R., and M. Morris. 2001. A handbook for value chain research. Brighton: Institute for Development Studies.

Kenny, B. 2001. 'We are nursing these jobs': The impact of labour market flexibility on South African retail workers. In Is there an alternative? South African workers confronting globalisation, ed. N. Newman, J. Pape, and H. Jansen, 90-107. Cape Town: ILRIG.

Kirsten, J. 2011. Most SA farmers are small scale. Farmers' Weekly, 23 Sept, 38.

Liebenberg, F. 2013. South African agricultural production, productivity and research performance in the 20th century. PhD thesis, University of Pretoria.

Ligthelm, A. 2006a. Measuring the size of the informal economy in South Africa, 2004/o5. Pretoria: Bureau of Market Research.

Ligthelm, A. 2006b. Size estimate of the informal sector in South Africa. Southern Africa Business Review 10, no. 2: 32-52.

Louw, A., L. Ndanga, D. Chikazunga, and J. Jagwe. 2008. Restructuring food markets in the Southern Africa region: Dynamics in the context of the fresh produce sector. Synthesis of country findings. www.regoverningmarkets.org. 
M2. 1999. Norsk Hydro joins AECI in South African fertilizer JV. http://www.m2.com/m2/web/ story.php/1999801D6F12A66C32B9802568560041FEB3.

Mack, M. 2012. The supply chain evolution. Supermarket \& Retailer, April, 9-16.

Madima, T. 2006. The South African agro-processing sector overview. DTI presentation to KZN Trade and Investment Fair and Conference, Durban, 30 March.

Manyelo, K., W. Van Averbeke, and P. Hebinck. 2014. Smallholder irrigators and fresh produce street traders in Thohoyandou, Limpopo Province, South Africa. In Rural development and the construction of new markets, ed. P. Hebinck, J. Douw van der Ploeg, and S. Schneider, 131-150. Oxon and New York: Routledge.

Martiniello, G. 2015. 'Don't stop the mill': South African sugar business, agrarian change and out-growers' schemes in the Kilombero Valley, Tanzania. Paper presented at 'Rural transformations and food systems: The BRICS and agrarian change in the global South' conference, Cape Town, 20-21 April 2015.

Massmart. 2014. Integrated annual report 2014. http://www.massmart.co.za/iar2014/.

Mather, C. 2005. The growth challenges of small and medium enterprises (SMEs) in South Africa's food processing complex. Development Southern Africa 22, no. 5: 607-22.

McMichael, P. 2005. Global development and the corporate food regime. New Directions in the Sociology of Global Development Research in Rural Sociology and Development II: 269-303.

Mirowski, P. 2014. Never let a serious crisis go to waste: How neoliberalism survived the financial meltdown. London and New York: Verso.

Moore, J. 2010. Cheap food and bad money: Food, frontiers, and financialisation in the rise and demise of neo-liberalism. Review 23, no. 2/3: 225-61.

Moss, M. 2013. Salt, sugar, fat: How the food giants hooked us. New York: Random House. Mountford, S. 2015. Why is big food in bed with dieticians? Follow the money. BizNews.com, May 30. http://www.biznews.com/health/age-well/2015/05/30/whyis-big-food-in-bed-with-dietitians-follow-the-love-of-money/.

Ntloedibe, M. 2015. South Africa food service - Hotel, restaurant, institutional sector report 2014. USDA Global Agricultural Information Network (GAIN) report. Washington, DC: United States Department of Agriculture.

Ogando, N. 2014. South Africa retail food industry. USDA Global Agricultural Information Network (GAIN) report, 22 August. Washington, DC: United States Department of Agriculture.

Pardhun, D. 2011. Losing out to supermarkets: The transformation of fruit and vegetable supply chains in Southern Africa. https://www.academia.edu/4254678/Losing_out_to_Supermarkets_ The_Transformation_of_Fruit_and_Vegetable_Supply_Chains_in_Southern_Africa

Pioneer Foods. 2014. Integrated annual report 2014. http://www.pioneerfoods.co.za/downloads/2014/ Pioneer_IR_2014.pdf.

Popkin, B. 1993. Nutritional patterns and transitions. Population and Development Review 19, no. 1: 138-57. 
Public Investment Corporation (PIC). 2014. Integrated annual report, 2013/14. http://www.pic.gov.za/index.php/annual-reports/.

Public Investment Corporation (PIC). 2015. Listed investments. http://www.pic.gov.za/index.php/investments/listed-equities/.

Raikes, P., M. Jensen, and S. Ponte. 2000. Global commodity chain analysis and the French filiere approach: Comparison and critique. Economy and Society 29, no. 3: 390-417.

RCL Foods. 2014. Integrated annual report 2014. http://www.rclfoods.com/pdf/2014/2014 IntegratedAnnual ReportResults.pdf.

Retailer News. 2015. Massmart moves to shift investment focus to small manufacturers. http://www.fastmoving.co.za/news/retailer-news-16/massmart-moves-to-shiftinvestment-focus-to-small- manufacturers-7116.

Ronquest-Ross, L.-C., N. Vink, and G. Sigge. 2015. Food consumption changes in South Africa since 1994. South African Journal of Science 111, no. 9/10. Art. \#2014-0354. http://dx.doi.org/10. 17159/sajs.2015/20140354.

Senwes. 2014. Integrated annual report 2014. http://www.senwes.co.za/Files/main_Corporate/ Annual_reports/2014/Senwes\%20Integrated\%20Report\%20Eng\%202014\%20LR.pdf. Senwes. 2015. Company profile. http://www.senwes.co.za/en-ZA/Corporate/.

South African National Seed Organisation (Sansor). 2014a. South African seed market for agronomic crops, 2014/15. http://sansor.org/wp-content/uploads/2012/o8/2014-15Agronomy-Stats.pdf.

South African National Seed Organisation (Sansor). 2014b. South African seed market for horticultural crops, 2014/15. http://sansor.org/wp-content/uploads/2012/08/201415-Horticulture-Stats. pdf.

South African National Seed Organisation (Sansor). 2014c. South African seed market for forage and pasture crops, 2014/15. http://sansor.org/wpcontent/uploads/2012/08/2014-15-SANSOR-Forage-Stats1.pdf.

Shoprite Holdings. 2014. Integrated annual report 2014. http://www.shopriteholdings.co.za/ InvestorCentre/Pages/Integrated-Report.aspx.

Spies DC. 2011. Analysis and quantification of the South African red meat value chain. PhD thesis, Department of Agricultural Economics, University of the Free State.

Stats SA. 2010. Census of commercial agriculture, 2007. Pretoria: Stats SA.

Stats SA. 2011. Manufacturing industry: Financial 2011. Report No 30-02-03. Pretoria: Stats SA. Stats SA. 2013. Agricultural survey 2013 preliminary. Statistical release P1101. Pretoria: Stats SA. Stats SA. 2014a. Land transport survey (preliminary) August 2014. Statistical release P7162. Pretoria: Stats SA.

Stats SA. 2014b. Land transport survey (preliminary) October 2014. Statistical release P7162. Pretoria: Stats SA.

Stats SA. 2015a. Manufacturing: Production and sales (preliminary) April 2015. Statistical release P3041.2. Pretoria: Stats SA.

Stats SA. 2015b. Land transport survey (preliminary) April 2015, Statistical release P7162. Pretoria: Stats SA. 
Steyn, N. 2006. Nutrition and chronic diseases of lifestyle in South Africa. In Chronic diseases of lifestyle in South Africa 1995-2005. Technical report, eds. K. Steyn, J. Fourie, and N. Temple, 33-47. Cape Town: South African Medical Research Council.

Steyn, N., N. Myburgh, and J. Nel. 2003. Evidence to support a food-based dietary guideline on sugar consumption in South Africa. B World Health Organisation 81, no. 8: 599608.

Sturgeon, T. 2000. How do we define value chains and production networks? MIT Industrial Performance Center, Globalization Working Paper 00-010, Massachusetts: MIT.

Sulle, E. 2015. Sugarcane outgrowers and foreign capital in contemporary Tanzania. Paper presented at 'Rural transformations and food systems: The BRICS and agrarian change in the global South' conference, Cape Town, 20-21 April 2015.

Switzerland Global Enterprise (SGE). 2013. Premium food and beverage market in South Africa. Zurich: Switzerland Global Enterprise.

Teagle, A. 2016. Budget's battle of the bulge: How sweet is SA's sugar tax? Daily Maverick, 6 March, http://www.dailymaverick.co.za/article/2016-03-o6-budgets-battle-of-thebulge-how-sweet-is- sas-sugar-tax/\#.V8P6oKobL-k.

Thow, A.M., D. Sanders, E. Drury, T. Puoane, S. Chowdhury, L. Tsolekile, and J. Negin. 2015. Regional trade and the nutrition transition: Opportunities to strengthen NCD prevention policy in the Southern African Development Community. Global Health Action 8: 28338. http://dx. doi.org/10.3402/gha.v8.28338.

Tiger Brands. 2014. Integrated annual report, 2014. http://www.tigerbrands.co.za/invest2/results/.

Visser, M., and S. Ferrer. 2015. Farm workers' living and working conditions in South Africa: Key trends, emergent issues and underlying and structural problems. Report prepared for the International Labour Organization, Pretoria office.

Wegerif, M. 2014. Exploring sustainable urban food provisioning: The case of eggs in Dar es Salaam. Sustainability 6, no. 6: 3747-79.

Wholesale and Retail Sector Education and Training Authority (W\&RSETA). 2011. Independent food retailers in the Republic of South Africa: Can they ensure sustainability in an evoloving retail landscape? Pretoria: W\&RSETA.

Wills, G. 2009. South Africa's informal economy: A statistical profile. WIEGO Urban Policies Research Report, No.7. WIEGO.

$\begin{array}{lllll}\text { Woolworths. } & \text { 2014. Integrated annual }\end{array}$ http://www.woolworthsholdings.co.za/investor/ annual_reports/ar2014/whl_2014_integrated_reprt1.pdf.

$\mathrm{Wu}$ fraat, M. 2011. Direct store delivery versus centralised distribution. http://www.mwpvl.com/html/dsd vs_central_distribution.html. 


\section{Appendix}

Table A1. Preliminary quantification of value in the agro-food system with sources and notes.

\begin{tabular}{|c|c|c|}
\hline Node & $\begin{array}{l}2014 \text { value of } \\
\text { sales (billion R) }\end{array}$ & Source and notes \\
\hline Food wholesale and retail total & 519.4 & $\begin{array}{l}\text { Ogando (2014) - figures don't add up correctly } \\
\text { in the USDA report but this is a close } \\
\text { approximation (added category amounts and } \\
\text { multiplied by USD/ZAR } 1: 10.6 \text { ) }\end{array}$ \\
\hline $\begin{array}{l}\text { Food and beverage } \\
\text { manufacturing }\end{array}$ & 391.9 & $\begin{array}{l}\text { Stats SA ( } 2015 \text { a) } \\
\text { Beverages R } 107.2 \text { bn ( } 27 \%) \text {; 'meat, fish, } \\
\text { fruit, etc.' (fresh produce) R } 105 \text { bn }(27 \%) \text {; } \\
\text { grain mill products R } 64.1 \text { bn }(16.4 \%) \text {; dairy } \\
\text { R } 34 \text { bn }(8.7 \%) \text {; other food products R } 81.6 \\
\text { bn }(20.8 \%)\end{array}$ \\
\hline $\begin{array}{l}\text { Traditional grocery retailers } \\
\text { and independent small } \\
\text { grocers }\end{array}$ & 291.5 & Ogando (2014) - as above \\
\hline $\begin{array}{l}\text { Formal food and beverage } \\
\quad \text { retail }\end{array}$ & 227.9 & $\begin{array}{l}\text { Ogando (2014) - as above } \\
\text { Supermarkets R } 181.3 \text { bn; other categories } \\
\text { are convenience stores, hypermarkets and } \\
\text { discounters }\end{array}$ \\
\hline $\begin{array}{l}\text { Primary agricultural } \\
\text { production }\end{array}$ & 208.3 & $\begin{array}{l}\text { DAFF (2015) } \\
\text { Animal production R } 96.4 \text { bn; field crops R } \\
58.5 \text { bn; horticulture R } 53.3 \text { bn }\end{array}$ \\
\hline $\begin{array}{l}\text { Current inputs to primary } \\
\text { agricultural production total }\end{array}$ & 138.2 & $\begin{array}{l}\text { Stats SA (2013) for } 2013 \text { figure of R } 130.1 \text { bn; } \\
\text { and DAFF (2015) for increase in farm input } \\
\text { prices to get a } 2014 \text { figure }\end{array}$ \\
\hline
\end{tabular}

(Continued) 
Table A1. Continued.

\begin{tabular}{|c|c|c|}
\hline Node & $\begin{array}{l}2014 \text { value of } \\
\text { sales (billion } \mathrm{R} \text { ) }\end{array}$ & Source and notes \\
\hline Listed retail property funds & 117.7 & $\begin{array}{l}\text { Financial Mail }(2015 b) \\
\text { Value of retailing properties }\end{array}$ \\
\hline Finance to farms & 116.6 & DAFF (2015) \\
\hline $\begin{array}{l}\text { Food exports processed and } \\
\text { unprocessed }\end{array}$ & 81.3 & DAFF (2015) \\
\hline Consumer foodservice & 78.3 & Euromonitor (2015d) \\
\hline $\begin{array}{l}\text { Food imports processed and } \\
\text { unprocessed }\end{array}$ & 61 & DAFF (2015) \\
\hline $\begin{array}{l}\text { Animal purchases for primary } \\
\text { production }\end{array}$ & 29 & Stats SA (2013) inflated by $5 \%$ for 2014 figure \\
\hline Animal feed & 27.8 & $\begin{array}{l}\text { Stats SA (2013) for } 2013 \text { figure of R } 26.6 \mathrm{bn} \text {; } \\
\text { and DAFF (2015) for increase in feed prices } \\
\text { to get a } 2014 \text { figure }\end{array}$ \\
\hline $\begin{array}{l}\text { Food and beverage containers } \\
\text { and packaging }\end{array}$ & 21.6 & $\begin{array}{l}\text { Stats SA (2011) for } 2011 \text { figure of R } 16.6 \mathrm{bn} \text {; } \\
\text { and DAFF (2015) for increase in packing } \\
\text { material prices to get a } 2014 \text { figure }\end{array}$ \\
\hline $\begin{array}{l}\text { Transport out }- \text { manufactured } \\
\text { food, beverages and tobacco }\end{array}$ & 15.1 & Stats SA (2014a, 2014b, 2015b) \\
\hline Fertiliser & 10.3 & $\begin{array}{l}\text { Stats SA (2013) for } 2013 \text { figure of R } 10 \mathrm{bn} \text {; and } \\
\text { DAFF (2015) for increase in fertiliser prices } \\
\text { to get } 2014 \text { figure }\end{array}$ \\
\hline $\begin{array}{l}\text { Freight transport primary } \\
\text { including forestry }\end{array}$ & 10.2 & Stats SA (2014a, 2014b, 2015b) \\
\hline Seed and plant material & 5.5 & $\begin{array}{l}\text { Sansor }(2014 \mathrm{a}, 2014 \mathrm{~b}, 2014 \mathrm{c}) \\
\text { Agronomy R } 4.1 \text { bn }(77 \% \text { maize); } \\
\text { horticulture R } 0.9 \text { bn; forage and pasture R } \\
0.5 \text { bn }\end{array}$ \\
\hline
\end{tabular}

Notes: Italics indicate sub-sectors in broader categories (e.g. 'traditional grocery retailers' under wholesale and retail total). bn: billion; USDA: United States Department of Agriculture. 